\title{
Language rights and education of the small numbered indigenous peoples of the European North of Russia: from the Soviet period to modern time
}

\author{
Vadim Atnashev ${ }^{1}$, Art Leete $^{2}$, Natalya Komelina ${ }^{3}$, Arina Bildyug ${ }^{3}$, and Elena Eltc ${ }^{*}$ \\ ${ }^{1}$ St. Petersburg State University, 7/9, Universitetskaya Emb, St.-Petersburg, 199034, Russia \\ ${ }^{2}$ University of Tartu, 18, Ülikooli, Tartu, 50090, Estonia \\ ${ }^{3}$ Institute of Russian Literature (Pushkin House), Russian Academy of Sciences, 4, Makarova Emb., St.- \\ Petersburg, 199034, Russia
}

\begin{abstract}
The article examines the experience of Russian constituent entities (Murmansk region, Nenets Autonomous Okrug, Archangelsk Oblast) in the support of indigenous ethnocultural rights in the context of current models for protection of minority languages and initiatives in the field of education. The contemporary scene of interaction between the state and indigenous minorities in the region is considered from a historical perspective. Special attention is paid to the early decades of the Soviet regime when key discussions concerning the status, way of integration with the state and direction of cultural development were established. The cultural bases and boarding schools, collectivization, forced relocations contributed to the construction of social reality of indigenous peoples which we can observe in the post-Soviet period. The specificity of modern transformation in the sphere of language and life of the reindeer herders are discussed in the context of the everyday practices of the interethnic relations of the Nenets and the Pomors of the Kanin peninsula and the northern parts of Mezen Region.
\end{abstract}

\section{Introduction}

Culture and language are the main elements of the identity preservation, therefore the support of the culture of minorities is necessary to protect them from assimilation and is vital for their survival in general. The UN Declaration on the Rights of Indigenous Peoples recognizes the right of these peoples to selfdetermination, autonomy and self-government, to complete freedom in the development of their economic, social and cultural institutions.

The definition of the concept of an indigenous people is contained in the International Indigenous and Tribal Peoples Convention, 1989, which obliges states to use special means to protect representatives of these peoples, their institutions, property, labor, tradition, culture and environment, as well as to provide conditions for the preservation of indigenous languages.

The UN indigenous right bodies highlight cultural loss and assimilation as the main reasons for the disappearance of indigenous languages. The Arctic peoples also face with such challenges, more or less acutely, depending on a country's situation. The practice of placing indigenous children in boarding schools, applied by governments in many regions of the world, has led to the children's assimilation, since their ties with their culture, language, and traditions were destroyed. It largely concerns the Russian North. All four dialects of the Sami language spoken in Russia are represented in the UNESCO list of languages in danger. Among the most pressing problems of Saami and Nenets of European North of the Russia are the low level of development of traditional activities, decrease in motivation for learning the native language, weak media coverage of the traditions, living conditions and life (which, like the projects "Voice of the tundra" and «Kola Saami Radio» is largely initiated within the framework of international cooperation in the north of Europe).

As a report on Russia presented at the UNPFII indicated in 2010, in many regions of Russia rural schools were closed. "Learning native languages is not only limited, but practically abandoned altogether.... Powers in the culture sphere have been delegated to the municipal level and the culture sector is financed in the last turn" [1]. Steps implemented to support the traditional culture and languages of small indigenous peoples in the regions, which are under discussion in this study, don't stop the threat of their assimilation and loss of languages.

\section{Cultural development of indigenous people in the north-west of Russia in the early Soviet era}

The contemporary scene of interaction between the state and indigenous 
minorities in the region was very much shaped by specific reforms, employed since the early decades of the Soviet regime. It was the epoch when key discussions concerning the status, way of integration with the state and direction of cultural development were established. Central topics of these discussions focused on the degree of autonomous development that ended by the 1930s with the official decision to integrate the northern peoples tightly to the general progress of the state and a possibility of special ways of evolution was denied. Establishment of cultural bases and boarding schools, collectivization and forced relocations changed people's life in indigenous communities fundamentally and produced social reality for them in the way we can observe it also in the post-Soviet period.

\subsection{Missionaries of Socialism and Culture bases}

The Committee of the North was established in 1924 and it implemented two strategies of modernising the indigenous peoples of the North. Following the first approach, proposed by Vladimir Bogoraz-Tan [2: 4850], 'missionaries of the new culture' were sent to taiga and tundra for facilitating socialist change among the indigenous groups. These 'missionaries of socialism' were young professional ethnographers, educated after the tsarist time, willing to explore indigenous culture in deep and having new, socialist ideals. They were supposed to provide practical help in turning indigenous peoples into socially self-conscious and economically self-sufficient social agents, able to follow the socialist path of development on their own.

Soon it became clear that a small number of inexperienced experts could not fulfil these gigantic plans of reorganising the life of the indigenous minorities. A more structural strategy was needed, and the Committee of the North introduced a more comprehensive plan of reforming the North by constructing culture bases. This was the most complex and intriguing socialist experiment conducted by the Soviets in the Arctic. The construction of culture bases was decided in 1925 [3: 111]. Nineteen culture bases were established in the remotest regions of the Russian North, Siberia and Far East by the end of the 1930s. Culture bases were exemplary settlements, built for indigenous groups in different regions of the North and consisting culture houses and many objects of infrastructure.

Culture bases were assumed to provide essential benefits and services typical of a modern society. These new settlements were meant to convince indigenous peoples in superiority of the Soviet life [4: 107]. Experts of the Committee of the North outlined the idea that culture bases must be founded in the areas almost entirely inhabited by natives, surrounded by native regions and characterised by a traditional way of life (as "the main hearth of the indigenous culture"). A culture base had to be established in order to influence the strongest indigenous groups and through them the surrounding communities. Through a chain mechanism of "self-influence," culture bases should execute Soviet control over indigenous communities in rather large territories. Special attention was supposed to be paid to preparation of specialists of indigenous origin. $[5,6,7$ : 77-79].

Despite ambitious plans, actual impact of the culture bases on indigenous population remained somewhat limited. Culture bases' budget was insufficient; they lacked means of transportation, and even food and heating [8: 46]. Besides, there was a general scarcity of suitable employees [9: 41, 66]. The problem of lacking competent staff concerned also the challenge of developing literacy in indigenous languages. Schoolbooks in languages of the northern peoples were published but it is complicated to estimate how many teachers were capable to use these textbooks in practice [10: 208].

Potential effect of culture bases was significantly restricted by resistance from local administrators and indigenous groups who mostly just evaded invasion of the Soviets to the tundra, until it was still possible. However, violent episodes of resistance and even indigenous uprisings took also place during the 193040s, especially in the Western Siberia [4: 103-117, 11: $167-176,12,13,14]$. This lack of enthusiasm by the indigenous population slowed considerably down reforms, induced through culture bases in tundra. After the Committee of the North was liquidated in 1935, the culture bases were handed over to the Glavsevmorput and later officially dismissed but these settlements exist also nowadays as administrative centres or economic meeting points for indigenous people.

\subsection{Soviet reforms in the Russian North}

'The missionaries of socialism' managed to facilitate organising cooperative production units among the Nenets and Pomors in the Russian North [2: 50]. By 1927, all Nenets of Small Land tundra belonged to these small cooperative units [15: 83, 16: 135]. However, these new 'missionaries' were not able to initiate principal innovation in the local communities. Therefore, culture bases became the next step of socialist reforms also in the Russian North. In the region, two culture bases were built - in Khoseda-Khard (Big Land tundra) among the very first culture bases [5: 36, 17: 84] and Kolokolkovo (Small Land tundra) in the later phase of establishing culture bases.

As there were no medical facilities in the tundra of the Russian North (as well as among the indigenous groups of Siberia) until the 1920s [2:45], 'flying squads' of medical workers were arranged for the Nenets of the Big and Small Land tundra (and for some other peoples 
of the Soviet Arctic) [15: 82, 16: 135-136, 17: 82, 18: 102]. In the late 1930s, construction of the hospital in Kolokolkovo culture base was not finished yet and most of equipment and medical staff was still missing. Despite this, the small existing staff of the hospital worked hard in order to convince the Nenets to visit hospital regularly. The staff travelled around the tundra, providing medical help. Doctors had a mobile sauna with them and, they managed to encourage hundreds of Nenets to visit that tent-sauna. Later, the mobile sauna was attached to the red tent as an attribute of Soviet propaganda [19].

There were other conditions or achievements of the Committee of the North that distinguished the Russian North from the rest of the Soviet Arctic. Here, schools were more common even from tsarist time, teachers with experience of working with indigenous children were available and it was easier to arrange educational work for indigenous groups [15: 79, 16: 135, 20: 20]. The $10^{\text {th }}$ extended plenary meeting of the Committee of the North issued the statement that nomadic councils, as newly established bodies of indigenous self-administration, functioned better in the Nenets National Region in the Russian North than in Siberia [16: 135, 21: 140]. Situation in the Russian North was so promising that even utopic economic experiments were introduced here. In 1926, Arkhangelsk regional Committee of the North initiated experiments of reconditioning a growth of moss in tundra and an experimental reindeer station was established on Kolguyev Island [22: 89].

On Kola Peninsula, no culture bases were established but similar trends of development can be traced. The indigenous minority policy in the region was rather weak during the 1920s and 1930s, when the Committee of the North enforced reforms in other parts of the Soviet Arctic [23: 46]. It has been argued that the Kola Sami suffered more than Nenets people did during the Stalin era because of "the border-transcending aspect" of the Sami population. However, repressions and devastative effect of collectivisation and boarding schools was rather common among the indigenous groups in the USSR [4: 110-115, 11: 176-178, 23: 47-48].

Decades later, the Kola Sami elders remembered collectivisation and the first wave of resettlement during the $1930 \mathrm{~s}$ and $1940 \mathrm{~s}$ as relatively smooth social challenge. The Sami population was relocated from tundra to small native villages. They lost their nomadic way of life but continued to dominate their social and cultural environment. But the second resettlement reform (from the 1950s to 1970s) had devastative consequences. Almost all the Kola Sami were removed to Lovozero village where they were amalgamated with the Russians, Izva Komi and Nenets, remaining socially and economically marginalised minority [23: 46-48, 24].

The Committee of the North found consistently positive examples of development (indigenous education, self-administration, health care, economic cooperation) from Big and Small Land tundra. Overall estimation of progress in socialist reforms among indigenous and non-indigenous population of the Russian North was also one of the highest among regions of the Arctic [25: 111, 116, 120].
On the basis on presented assessments, it can be argued that reforms of the Committee of the North were more successful in the Russian North than in Siberia. However, from the second half of the 1930s, after the Committee of the North was dismissed in 1935, prospects of successful integration of indigenous population into a larger society were lost. The potential of special development of indigenous groups in the Russian North did not materialise (local indigenous councils and courts were abolished, kolkhozes and boarding schools sustained). From the end of the 1930s, no distinctive indigenous policy was implemented in the Soviet Union.

\section{The current experience of Russian constituent entities in the support of indigenous ethnocultural rights}

Arctic settlements preserve the memories of 'missionaries of the new culture', the enthusiasts of the 1930s, mobilized and called up by the revolution, who worked and roamed in the tundra, who treated the indigenous population with respect and investigated the life of reindeer herders. Widely known ones are the names of N. Karpov, the founder of a nomadic school for children and youth on the Kaninsky Peninsula; doctor A. Koroliov, who made weekly visits from the hospital to the reindeer herders' camps in the Nes' village. Since the 2000s several projects have been implemented in the Nenets Autonomous Okrug, using the models of the late 1920s-1930s.

A social project "Red Tent" to ensure the availability of medical care for the nomadic population in remote regions was launched at the initiative of the "Association of the Nenets People "Yasavey", and with the support of the district administration, as well as the oil business. The project received a long-term planning character.

At the heart of the debate is the need to revive nomadic schools, an example of which was the school in the village Shoyna back in 1930-1935. Restoring the nomadic educational model in the late 1990s was a joint initiative of the administration of the Nenets Okrug, along with the Norwegian Barents Secretariat. It was associated with the urgent need to adapt a group of Nenets reindeer breeders, most of whom were illiterate and did not know Russian, to the modern socioeconomic conditions of the region. In view of current urgent problems of preserving the Nenets language, the nomadic schools are considered as the practice of strengthening the language of the indigenous people and hereditary transmission from generation to generation, the model of a boarding school for children of reindeer herders is associated with economic advantages, and therefore, it often seems to be more preferable.

The pilot project of the nomadic «Kaninsky (tundra) kindergarten», launched in 2016 and financed under the regional state program is often assessed as an instrument of adaptation to studies in boarding schools in Nes' and Shoyna rural settlements. Due to the factual lack of children's skills in speaking their native language, only 
the elements of the Nenets language were used in joint games, in the classroom and in communication.

The opportunity to learn native language and to study in the Nenets language is enshrined in the regional law on the Nenets language. There are schools where the native (Nenets) language is being studied in municipal districts, where the share of the Nenets population exceeds the half, as well as in the city of Narian-Mare. The mother tongue is taught optional or as a national regional component of the curriculum, in grades 1-9 (with parental consent) and takes 2 hours a week. However, under the conditions of development of ethnic identity among the indigenous peoples, associated with the revival of the original culture, economy and language, since the 1990s, situations arise, when the children of reindeer herders (Nenets, Izhma-Komi) drop out of school after four years of study [26].

The current interest in wider dissemination of the nomadic school model, which will require changes to the regional law on education, teachers' training and additional funding, arose against the background of the approval of this model within the framework of the Euro-Arctic Barents Cooperation, Council of Europe as well as the successful experience of neighboring regions - Yamalo-Nenets Autonomous Okrug and the Republic of Sakha.

The end point of the winter routes of the Kaninsky reindeer herders is the Mezensky and Pinezhsky districts in the Archangelsk Oblast, where the Pomor identity is most clearly expressed. The districts' pasturelands were given in long-term lease to Kanin reindeer herders' teams. The inhabitants of the Mezen villages (Ruchyi and Dolgoshchelye) have abandoned reindeer husbandry in the absence of state support and due to a high land tax, of which the Nenets of the Nenets Autonomous Okrug are exempted.

Currently, 175 Nenets (1\%) live a sedentary life in the Mezensky region. However, in 2018, the Council of Civil Society Development and Human Rights under the President of the Russian Federation recommended adding the municipal district to the list of places of traditional residence of the Nenets. Nevertheless, the proposal has been subject to widespread criticism, as potentially contributing to increased conflict between the Nenets and Pomors.

The mistakes of the second half of the XX century, related to the radical breakdown of the economic and everyday life of the Kola Sami, violation of the system of traditional upbringing of children, the transformation of individual farms into collective and state farms, the resettlement of indigenous peoples to larger settlements have been officially recognized in the Murmansk region. Since the 1970s the Kola Sami are concentrated in four settlements, while they are adjacent to other ethnic groups: Lovozero - the cultural capital of the Sami (Sami, Komi, Nenets, Russians); Krasnoschelye (Sami, Komi), Tuloma (Sami, Russians), Ena (Sami, Finns, Karelians).

The emphasis on the danger of losing the language of the Kola Sami, in the face of a decrease in the number of speakers, and the predominant role of enthusiasts in the transfer of knowledge, was put forward by the working group on the indigenous peoples of the Barents region. However, the Sami language is currently only taught as a one-hour-a-week elementary class at the only boarding school in Lovozero.

\section{The Nenets and the Pomors of the Russian North: "Now all are confused..."}

Our case study aims to add some touches to the scene of modern changes in the reindeer herders' everyday life through the narratives of the Nenets and the Pomors around this subject. Recently, the process of sedentarization of nomadic population is under discussion along with the problem of adaptation of the reindeer herders to economic transformations, gender shift in tundra communities, and the role of village in the nomadic identity [27, 28, 29: 80-83]. The same problems of Nenets community on Kanin peninsula (Nenets Autonomous Okrug) are also discussed in a number of works [30, 31, 32: 16-22, 33].

Our work is based on the results of fieldwork of Pushkin House (seasons 2014 and 2016) in villages Koyda and Dolgoshchelye of the northern part of Mezen' Region of Archangelsk Oblast. The materials of fieldwork 2006-2007 on Kanin peninsula are included, as well. It was conducted in terms of joint project of University of Aberdeen and Faculty of History, SaintPetersburg State University. The Kanin peninsula and the northern part of Mezen' Region are the territories of the reindeer-herding by the Nenets and the Izhma-Komi 30: 6]. The Pomor villages started to appear on these territories from the $16^{\text {th }}-18^{\text {th }}$ centuries. Village Shoyna was founded on Kanin peninsula as the centre for fishing at the Soviet times.

During the last decades, the intensifying process of sedentarisation of reindeer herders has formed stronger ties between nomads and sedentary groups of the Nenets people (for the same on Yamal see Stammler [29: 8083]). At the same time it has led to the closer inter-ethnic relations between the Nenets and the Russians in the field of everyday life in the villages: horticulture, leisure and so on [33]. Our informants mentioned the following reasons of sedentarisation: the inaptitude of someone for reindeer herding (problems with orientation in tundra, difficulties in the reindeers earmarks distinguishing, etc. (the Archive of the Department of Ethnography and Anthropology, the Institute of History, Saint-Petersburg State University, Northern expedition - 2006, Field Notes, Bildyug A. (further in the text - FN 2006): 19)); difficult living conditions in tundra; reluctance of young people to nomadic life (FN 2006, 20; Digital Fund of the Phonogram Archive of the Institute of Russian Literature (Pushkin House) RAS (further in the text - FA DF) 905A039-04; for comparison see Liarskaia [34: 55-58]); a lack of money; the system of boarding schools (FN 2006: 19-20). 
The ongoing changes are considered as rather complicated by the Nenets and the Pomors both: "If they settle, then they are not in their own surroundings," "people feel themselves confused" (FN 2006: 18). The reindeer herders "are being pressed". However, very often our informants related the reasons of the conflicts to bad tempers of its parties, regardless of their ethnicity. The stories about the alcohol addiction of the Nenets form the special group in the narratives about conflicts (on stereotypes of this kind see Leete [35]; Dudeck [36]). But still in these cases the boarder of the collision lay to a greater extent between settled group of people (the Nenets and the Pomors both) and the nomads (toundroviki) (FN 2006: 11, 13-14). Conflicts, which reasons can be traced to the ethnicity, are often provoked by the difficulties in the legal status of sedentary and nomadic peoples, still living in the same conditions of the North: "The Mezenians were not allowed to fish for flounder at the sea, so the Mezenians do not allow reindeer herders to stay at the forests, they shoot their reindeers. They say, Mezen' is not NAO" (the Archive of the Department of Ethnography and Anthropology, the Institute of History, Saint-Petersburg State University, Northern expedition - 2007, Field Notes, Bildyug A. (further in the text - FN 2007): 14 (see also: FN 2007: 6)).

The process of sedentarisation leads to gradual fading of the Nenets language on Kanin peninsula and Mezen' Region. People there can use three languages (including Komi) in their everyday practices (Ushakov [31:7]; FN 2006: 7). Our informants noticed that the Nenets language is used mostly in the tundra, since a lot of special phenomena related to the everyday nomadic life can't be properly reflected in another way. But on the whole, nowadays the Russian language is the main one almost for all the Nenets of Kanin peninsula and Winter coast (FN 2006: 7): "That's it, now that's it. And why did they forget what is theirs? Young people do not speak at all, well, there are some girls who already do $\langle\ldots\rangle$ and the rest, they now do not speak it at all..." (FA DF 908A004-01). The problem of language is closely related to the interethnic marriages, which were not common before. More often the wives learn the language of their husbands (FN 2006: 7). Usually the Nenets girls marry the Pomors and stay in the villages, but sometimes the Pomor girls move to tundra and start the nomadic life, which is more surprising for their neighbors: "They told her, where you are going, what all this is for?" (FA DF 905-A039-04) (on gender shift in tundra see Liarskaya [34]).

In the narratives related to the everyday life and the Pomor-Nenets interethnic relations the ongoing changes are reflected in the opposition of the well-ordered past and somewhat chaotic present: "They used to respect/follow (sobljudali) everything before. <...> Now all are confused/mixed up (zapoutalis')" (FA DF 905A037-01).

\section{Conclusion}

The territory of indigenous peoples, which are vital for their subsistence, cultural and spiritual life and for achieving and implementing autonomy and selfgovernment, should be guaranteed to them. Though the constitutions of the Russian Federation and its subjects (e.g. the Charter of the Nenets Autonomous Okrug) recognize the right to preserve and develop the languages and cultures of indigenous peoples, the effectiveness of various programs is limited.

The only way of language revitalization is associated with a change in the status of the language through the formation of language policy and the expansion of the spheres of language functioning and training of civil servants in indigenous languages. In particular, it is necessary to provide intercultural and multilingual education for the entire population of the Russian Arctic. The governments, both Soviet and Russian ones, more often have just worried about teaching the official, state language. At the local level, measures to preserve practice of the indigenous languages are very weak let alone to promote their development.

Acknowledgements. The work was supported by the University of Tartu (grant PHVKU19913, 2019-2021) and the Russian Science Foundation (grant 17-78-20194, 2020-2021).

\section{References}

1. Indigenous peoples: development with culture and identity: articles 3 and 32 of the United Nations Declaration on the Rights of Indigenous Peoples Report of the international expert group meeting, 12 - 14 January 2010, Retreived from: https://undocs.org/E/C.19/2010/14 (12 June 2020)

2. V. Bogoraz-Tan, Northern Asia [In Russian] 3, 40-50 (1925)

3. The protocol of the extended plenary meeting of the Committee of the North with the delegates of the $12^{\text {th }}$ Congress of the Soviets of the RSFSR Northern Asia [In Russian] 3, 111 (1925)

4. M.M. Balzer, The Tenacity of Ethnicity. A Siberian Saga in Global Perspective. (Princeton University Press, Princeton, 1999).

5. A.K. Lvov, Northern Asia [In Russian] 3, 28-37 (1926)

6. V.M. Novitskii, Ural Regional Studies [In Russian] 2, 117-124 (1928a)

7. V.M. Novitskii, Northern Asia [In Russian], 5-6, 68-73 (1928b)

8. P. Terletskii, Soviet North [In Russian] 1, 36-48. (1935)

9. E.D. Kantor, Soviet North [In Russian] 6, 66-68 (1933)

10. E. Toulouze, L. Vallikivi, A. Leete., Ethnic and Religious Minorities in Stalin's Soviet Union: New Dimensions of Research, 199-223 (Södertörn University, Huddinge, 2017)

11. A. Golovnev, Talking Cultures: Samoyed and Ugrian [in Russian] (Ural Branch, Russian Academy of Science, Ekaterinburg, 1995) 
12. O.D. Ernykhova, The Kazym Rebellion: About the History of Kazym Uprising 1933-34 [in Russian] (Siberian chronograph, Novosibirsk, 2003)

13. A. Leete, Temenos - Nordic Journal of Comparative Religion 39-40, 235-245 (2004)

14. A. Leete, Asian Folklore Studies 64(2), 233-246 (2005)

15. Extended plenum of the Committee of the North at the Board of The All-Russian Central Executive Committee (from 28/II to 5/III 1927) Northern Asia [In Russian] 3, 76-90 (1927)

16. K.S. Korelin, in The 1926/27 Soviet Polar Census in the Russian North (Arkhangelsk province and autonomous region of Komi) [In Russian], 127139 (EthnoExpert St-Petersburg, 2010)

17. Work Results of the Committee for Assistance to the Peoples of the Northern Borderlands of the All-Union Central Executive Committee. Northern Asia [In Russian] 3, 80-85 (1926)

18. P. Khatanzeiskii, in. The 1926/27 Soviet Polar Census in the Russian North (Arkhangelsk province and autonomous region of Komi) [In Russian], 99-106 (EthnoExpert, St-Petersburg, 2010)

19. G. Khabarov, Soviet Arctic [In Russian] 5, 62-63 (1938)

20. A.V. Lunacharskii, Northern Asia [In Russian] 3, 18-22 (1927)

21. Presentation of Reports. Soviet North [In Russian] 3, 139-143 (1934)

22. Plenary Meeting of the Committee of the North . Northern Asia [In Russian] 3, 85-94 (1926)

23. M. Berg-Nordlie, Acta Borealia 32 (1), 40-67. (2015)

24. A. Afanasyeva, Forced relocations of the Kola Sámi people: background and consequences. (Thesis submitted for the degree: Master of Philosophy in Indigenous Studies.).( University of Troms $\emptyset$. 2013)

25. The protocol of meeting of the extended plenary meeting of the Committee for advancement of peoples of the northern peripheries at the Board of The All-Russian Central Executive Committee, held from the 7th to the 13th of March 1928. Northern Asia [In Russian] 4, 109-123 (1928)

26. M.Kh Belianskaia, Journal of Siberian Federal University 10, 2342-2350 (2016)

27. A.V. Golovnev, D.A. Kukanov, E.V. Perevalova, Arctic: Atlas of Nomadic Technologies [in Russian] (MAE RAS Publ, St. Petersburg, 2018)

28. E.V. Liarskaia, Anthropology. Folklore Studies. Linguistics [In Russian] 1, 36-55 (2001)

29. F. Stammler, Reindeer Nomads Meet the Market: Culture, Property and Globalisation at the End of the Land (Lit-Verlag, Muenster, 2005)

30. S.B. Kiselev, Traditional Economy of the Nomadic Population of the Kanin Peninsula in the First Third of the 20th Century and at the Beginning of the 21st Century. Thesis for a PhD in History [In Russian]. (St. Petersburg, 2018)
31. N.V. Ushakov, Field Study Materials MAE RAS [In Russian], 15, 6-22 (MAE RAS, SaintPetersburg, 2015)

32. S. Usenyuk, S. Dudeck, N. Garin, The Polar Journal 5(1), 170-202 (2015)

33. O.V. Sokolova, O.A.Subareva Field Study Materials MAE RAS [In Russian] 8. SaintPetersburg, 24 - 38 (2008)

34. E.V. Liarskaia Anthropology of East Europe Review 28, 51-84 (2010)

35. A. Leete, Acta Ethnographica Hungarica, 50 (1), 241-258 (2005)

36. S. Dudeck, Folklore 61 (August), 89-116. (2015) 